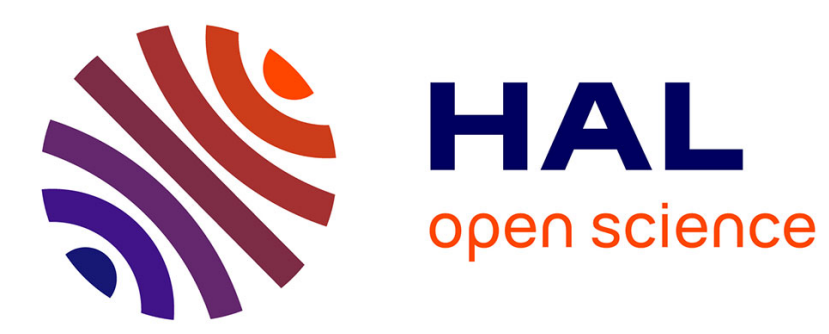

\title{
Crystallization study of amorphous Mn1-xCx films prepared by RF magnetron sputtering
}

\author{
A. Aouni, E. Bauer-Grosse
}

\section{To cite this version:}

A. Aouni, E. Bauer-Grosse. Crystallization study of amorphous Mn1-xCx films prepared by RF magnetron sputtering. Journal de Physique IV Proceedings, 1993, 03 (C7), pp.C7-2189-C7-2192. 10.1051/jp4:19937349 . jpa-00251997

\section{HAL Id: jpa-00251997 https://hal.science/jpa-00251997}

Submitted on 1 Jan 1993

HAL is a multi-disciplinary open access archive for the deposit and dissemination of scientific research documents, whether they are published or not. The documents may come from teaching and research institutions in France or abroad, or from public or private research centers.
L'archive ouverte pluridisciplinaire HAL, est destinée au dépôt et à la diffusion de documents scientifiques de niveau recherche, publiés ou non, émanant des établissements d'enseignement et de recherche français ou étrangers, des laboratoires publics ou privés. 


\title{
Crystallization study of amorphous $\mathrm{Mn}_{1_{-x}} \mathrm{C}_{x}$ films prepared by $\mathrm{RF}$ magnetron sputtering
}

\author{
A. AOUNI and E. BAUER-GROSSE
}

Laboratoire de Science et Génie des Surfaces, URA 1402 du CNRS, Ecole des Mines, Parc de Saurupt, 54042 Nancy cedex, France

\begin{abstract}
.
For the first time, $\mathrm{Mn}_{1-\mathrm{x}} \mathrm{C}_{\mathrm{x}}$ amorphous films with $0.20 \leq \mathrm{x} \leq 0.37$ were obtained by $\mathrm{RF}$ magnetron sputtering. Their thermal stability was studied by DSC and hot stage TEM. For $\mathrm{x} \leq 0.34$, the crystallization of amorphous alloys leads to the formation of known triangular prismatic sheet (TPS) carbides such as $\mathrm{Mn}_{3} \mathrm{C}$ and $\mathrm{Mn}_{5} \mathrm{C}_{2}$, and in addition, to the formation of new metastable TPS carbides having either periodic structures which correspond to $\mathrm{Mn}_{2 n+1} \mathrm{C}_{n}$ formula with $n=3$ and $n=4$ or onedimensional aperiodic structures with the $\mathrm{Mn}_{1-\mathrm{y}} \mathrm{C}_{\mathrm{y}}$ formula. This structure type can lead to the TPS $\mathrm{Mn}_{2} \mathrm{C}$ carbide which have been detected for $\mathrm{x}=0.34$. For $\mathrm{x} \geq 0.34$ a new percarbide $\mathrm{Mn}_{2} \mathrm{C}$, for which $\mathrm{C}$ atoms are in octahedral interstices, is observed.
\end{abstract}

\section{Introduction.}

The aim of this work is to study the structure and defects of metastable carbides which appear during the crystallization of amorphous Mn-C alloys, as was done for $\mathrm{Fe}-\mathrm{C}[1,2]$ and $\mathrm{Cr}-\mathrm{C}[3]$ systems. To our knowledge, $\mathrm{Mn}_{1-\mathrm{x}} \mathrm{C}_{\mathrm{x}}$ amorphous films have never been elaborated. Sputtering is a powerful tool to obtain these alloys and their crystallization can produce new manganese carbides. Among the known manganese carbides, there are TPS carbides such as $\mathrm{Mn}_{3} \mathrm{C}$ and $\mathrm{Mn}_{5} \mathrm{C}_{2}$ [4] and a TP chain carbide $\mathrm{Mn}_{7} \mathrm{C}_{3}$. $\mathrm{Mn}_{23} \mathrm{C}_{6}$ and $\mathrm{Mn}_{15} \mathrm{C}_{4}$ were also mentionned [5]. Nearly all of the structure of these manganese carbides was established through the great similarity between $\mathrm{Mn}-\mathrm{C}, \mathrm{Fe}-\mathrm{C}$ and $\mathrm{Cr}-\mathrm{C}$ systems.

\section{Experimental methods.}

$\mathrm{Mn}_{1-\mathrm{x}} \mathrm{C}_{\mathrm{x}}$ amorphous films were deposited by $\mathrm{RF}$ magnetron sputtering onto glass slide substrates using a pure $\mathrm{Mn}$ target and variable $\mathrm{Ar}-\mathrm{CH}_{4}$ gas mixture as reactive plasma. The carbon and manganese content were determined by EPMA. The structure of as-sputtered films and their crystallization were studied by X-ray diffractometry using a Mo source, differential scanning calorimetry (DSC) and hot stage JEOL $200 \mathrm{kV}$ transmission electron microscopy (TEM). 


\section{Results and discussion.}

Depending on the $\mathrm{CH}_{4}$ partial pressure, the carbon content of the films varies from $\mathrm{x}=0.13$ to $\mathrm{x}=$ 0.37. The X-ray analysis shows that when the atmosphere is $\mathrm{CH}_{4}$ free, the film is composed of the fcc $\mathrm{Mn}_{\alpha}$ phase without any preferential orientation. At a low $\mathrm{CH}_{4}$ partial pressure, the film is composed of a solid solution of $\mathrm{C}$ in $\mathrm{Mn}_{\alpha}$. For $0.20 \leq \mathrm{x} \leq 0.37$, the $\mathrm{X}$-ray diffraction patterns (figure 1), selected area diffraction and bright field TEM observations show that an increase of carbon content render the films amorphous. Then, no trace of cristallinity could be detected, in any of $x \geq 0.20$ as-sputtered films, either by $\mathrm{X}$-ray diffraction or by TEM.

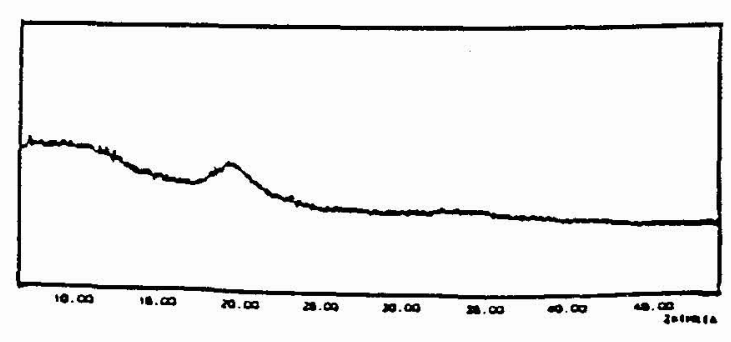

Figure $1 X$-ray difraction profile $\left(\lambda_{M_{0}}=0.07092 \mathrm{~nm}\right)$ of amorphous Mno.80 $\mathrm{C}_{0.20}$ film.

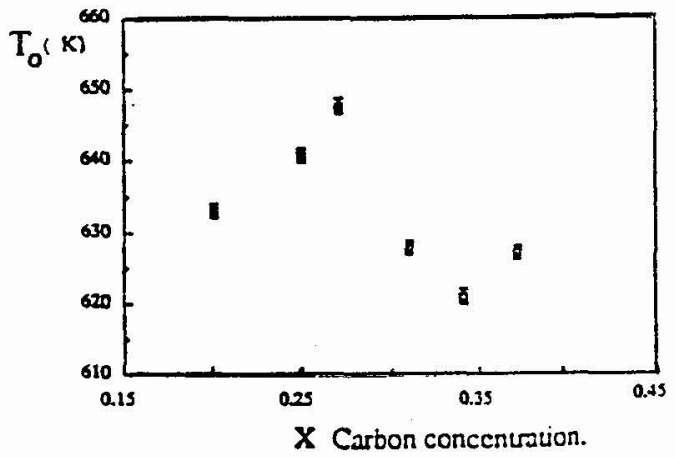
- Figure 2 Formation cemperature of mangancse carbides
as a function of $x$

The study of the stability of $\mathrm{Mn}_{1-\mathrm{x}} \mathrm{C}_{\mathrm{x}}$ amorphous alloys by means of DSC shows that the amorphous to crystalline state transition occurs as a direct transformation. Figure 2 shows the temperature $T_{o}$ of the carbide formation as a function of $x$, for amorphous samples heated at a rate of $8310^{-3} \mathrm{Ks}^{-1}$. This temperature shifts with carbon content. Thus, a maximum of $T_{0}$ exists around $x \approx 0.28$ and a minimum around $x \approx 0.34$. The same evolution was already observed for $\mathrm{Fe}_{1-\mathrm{x}} \mathrm{C}_{\mathrm{x}}$ alloys [2].

In the TEM, the samples are all heated with the same rate until crystalline phases are obtained.
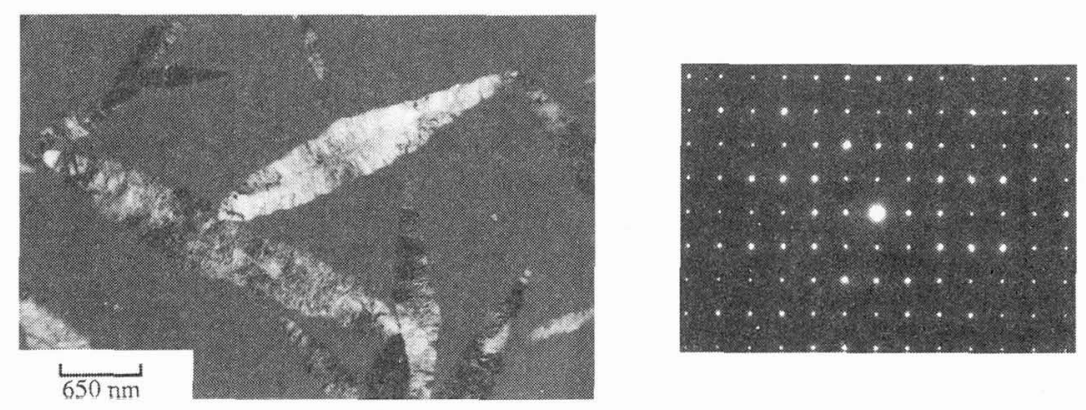

Figure 3 TEM micrograph showing the feather st ape morphology of TPS carbides and corresponding S.A.E.D obtained during the crystallization of a $\mathrm{Mn}_{0.75} \mathrm{C}_{0.25}$ amorphous film at $653 \mathrm{~K}$.

For $\mathrm{x}<0.34$, feather-shaped carbides appear as shown in figure $3 \mathrm{a}$ and the S.A.E.D patterns obtained from these crystals often correspond to the same zone axis (figure $3 b$ ). This pattern is characteristic of TPS carbides when the electron beam is perpendicular to the TP sheets, but it is not 
enough to determine which type of TPS carbides has been formed. For example, due to the similarity between $\mathrm{Mn}_{3} \mathrm{C}$ and $\mathrm{Mn}_{5} \mathrm{C}_{2}$, this pattern can correspond to a (001) $\mathrm{Mn}_{3} \mathrm{C}$ zone axis as well as a (100) $\mathrm{Mn}_{5} \mathrm{C}_{2}$ zone axis. To know the linkage between the TP sheets, it is important to find the diffraction patterns which contain the direction called $X^{*}$ perpendicular to these TP sheets. They are obtained nn more crystallized films and the figure 4 shows a set of these S.A.E.D patterns. Some of them have already been observed for the iron carbides and they can be described with the help of two sets of diffraction spots:

- a first set of diffraction spots is characteristic of the TPS and their position are almost independent of the carbon content. They will be considered as invariant. A two dimensional basic reciprocal lattice which is common to all the S.A.E.D patterns - except this one of figure $4 \mathrm{~b}$ - is drawn in figure $4 \mathrm{e}$.

- a second set of diffraction spots is related to the linkage between the TP sheets and we can distinguish two cases :

* This one for which the smallest distance between two invariant spots along $X^{*}$ is divided in equal parts by 6 spots ( figure 4a), 8 spots (figure 4b) and 1 spot (figure $4 \mathrm{c}$ ). These distributions correspond to new carbon-richer periodic TPS carbides which are respectively $\mathrm{Mn}_{7} \mathrm{C}_{3}, \mathrm{Mn}_{9} \mathrm{C}_{4}$ and $\mathrm{Mn}_{2} \mathrm{C}$. For the known $\mathrm{Mn}_{3} \mathrm{C}$ and $\mathrm{Mn}_{5} \mathrm{C}_{2}$ carbides, this distance will be divided respectively by 2 and 4 spots [2]

* This one for which the same distance is divided by four spots in five inequal parts. This kind of repartition corresponds to new one-dimensional aperiodic carbides for the $\mathrm{Mn}-\mathrm{C}$ system. In this case, second set diffraction spots are regarded as satellites of first set diffraction spots and only one parameter $\delta$ is needed to explain the position of satellites with varing carbon content. With this description, some particular values of $\delta$ lead to a periodic structure (For example $\mathrm{Mn}_{2} \mathrm{C}$ for $\delta=0, \mathrm{Mn}_{3} \mathrm{C}$ for $\delta=\frac{1}{3}$ and $\mathrm{Mn}_{5} \mathrm{C}_{2}$ for $\left.\delta=\frac{1}{5}\right)$. By measuring the $\delta$ value from the reciprocal plane of figure $4 \mathrm{~d}(\delta=0.113)$ and by interpolation between the previously particular $\delta$ values, it is possible to known the carbon content of this aperiodic TPS carbides which is $\mathrm{x} \approx 0.31$.All these carbides can be described by chemical twinning [2].

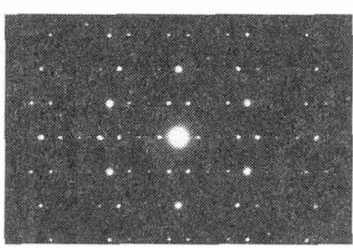

(a) $\mathrm{Mn}_{7} \mathrm{C}_{3}$

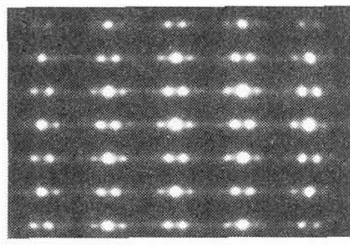

(d)

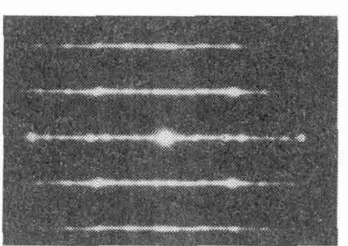

(b) $\mathrm{Mng}_{4}$ (c) $\mathrm{Mn}_{2} \mathrm{C}$

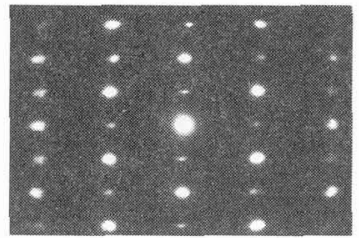

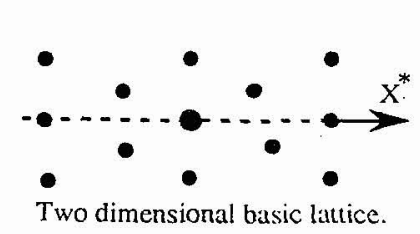

(e)

Figure 4 A set of periodic $(a, b, c)$ and aperiodic (d) TPS carbides S.A.E.D patterns obtained for different carbon concentration. 
For $\mathrm{x} \geq 0.34$, a new manganese carbide has been obtained (figure 5). It is a matter of the $\mathrm{Mn}_{2} \mathrm{C}$ percarbide which is isomorphous with $\mathrm{W}_{2} \mathrm{C}$ and $\mathrm{Fe}_{2} \mathrm{~N}[6]$ and for which $\mathrm{C}$ atoms are in octahedral interstices. The structure of this carbide is strongly dependent of the arrangement of $\mathrm{C}$ atoms and is hexagonal $L_{3} 3$ type when these atoms are randomly distributed on the octahedral sites. Ordering of $\mathrm{C}$ atoms leads to surstructures. The diffraction pattern of figure $5 \mathrm{~b}$ show diffraction spots characteristic of the $\mathrm{L}_{3}$ type structure, but also supplementary weak diffraction spots which can be interpreted with the orthorhombic $\zeta \mathrm{Fe}_{2} \mathrm{~N}$ type structure. In addition, we can notice diffusion lines which only affect this orthorhombic structure [7]. A further heating permits a perfect ordered arrangement of this structure. Further investigation will be made for $\mathrm{x}>0.37$.

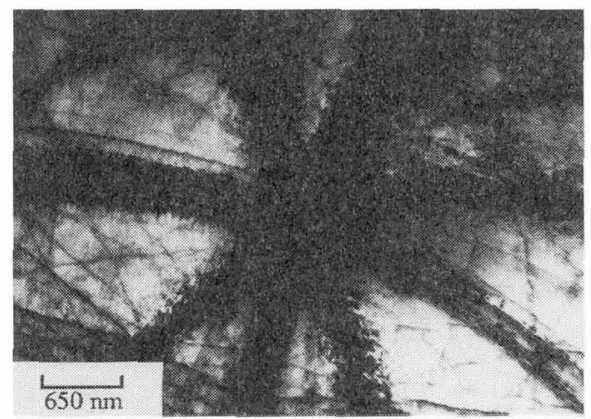

(a)

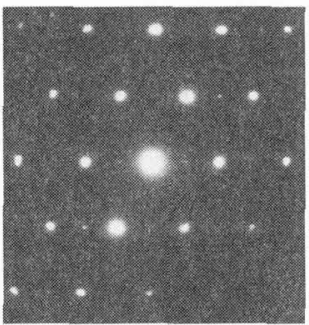

(b)

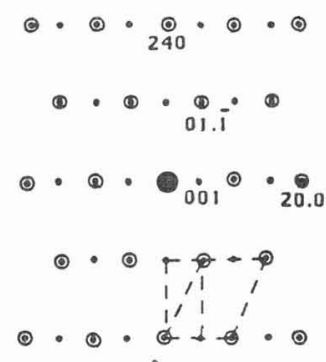

(c)

Figure 5 (a) TEM micrograph of $\mathrm{Mn}_{2} \mathrm{C}$ crystal which often forms bend contour contrast.

(b) S.A.E.D pattern and (c) its schematic tepresentation showing spots due to both

Conclusion. $\mathrm{L}_{3}$ and $\zeta \mathrm{Fe}_{2} \mathrm{~N}$ type latices.

The crystallization mechanism of $\mathrm{Mn}_{1-\mathrm{x}} \mathrm{C}_{\mathrm{x}}$ amorphous films changes drastically at $\mathrm{x}=0.34$ and leads, in addition to the known TPS $\mathrm{Mn}_{3} \mathrm{C}$ and $\mathrm{Mn}_{5} \mathrm{C}_{2}$ carbides, to new TPS carbides which can be periodic - thus we can detect $\mathrm{Mn}_{7} \mathrm{C}_{3}$ and $\mathrm{Mn}_{9} \mathrm{C}_{4}$ - or aperiodic and can reach the $\mathrm{Mn}_{2} \mathrm{C}$ formula. For $\mathrm{x}>$ 0.34 , a new $\mathrm{Mn}_{2} \mathrm{C}$ percarbide is observed. This crystallization mechanism change which is correlated to a minimum of the crystallization temperature corresponds to a change in the $\mathrm{C}$ atoms sites : below $\mathrm{x}=0.34$, all the $C$ atoms are in prismatic interstices and above this value the $C$ atoms set into octahedral interstices. This change in $\mathrm{C}$ atoms sites, for the first crystallization products, suggests that there is probably a change in the local order of amorphous state for a characteristic carbon content $x=0.34$. It is interesting to remark that it is possible to obtain two types of carbides - the TPS $\mathrm{Mn}_{2} \mathrm{C}$ carbide and the $\mathrm{Mn}_{2} \mathrm{C}$ percarbide for a same carbon content which is very close to 0.34 .

\section{References.}

[1] E.Bauer-Grosse, G.Le Caer : Mater.Sci.Eng, 99(1988)273.

[2] E.Bauer-Grosse, G.Le Caer : Mater.Sci.Eng, 99(1988)31.

[3] E.Bouzy, E.Bauer-Grosse, G.Le Caer : Mater.Sci.Eng, A133(1991)640.

[4] K.kuo and Persson. J.Ir.Steel Inst : 39(1954)178.

[5] J.P.Bouchaud : Ann.Chim., 2(1967)353.

[6] S. Nagakura, S.Oketani : Trans I.S.I.J, 8(1968)265.

[7] A.Aouni and E.Bauer-Grosse : to be published. 